\title{
LEGAL PRACTICES OF INSOLVENCY AND BANKRUPTCY IN INDIA
}

\author{
Dr. Sushama Yadav \\ Assistant Professor, Department of Commerce, School of Commerce \& Management, \\ Dr. Harisingh Gour University, Sagar-470003, Madhya Pradesh, India,
}

Article DOI: https://doi.org/10.36713/epra9303

DOI No: 10.36713/epra9303

\begin{abstract}
Bankruptcies have historically followed the business cycle closely. Failure of certain company strategies is a natural part of the market economy's process. When a firm fails, the optimum outcome for society is a quick renegotiation between financiers, to fund the going concern with a new structure of obligations and a new management team. The purpose of bankruptcy legislation is to recover an entity's debt and distribute its assets among competing claimholders. As a result, the RBI's asset quality reviewers identified an extremely high number of NPAs. The government's most major change is the insolvency and bankruptcy legislation.

On the heels of the adoption of the Insolvency and Bankruptcy Code, India jumpedfrom $108^{\text {th }}$ to $52^{\text {nd }}$ in the resolving insolvency category, while its rating improved significantly in dealing with construction permits to $27^{\text {th }}$ from $52^{\text {nd }}$ and trading across borders to $68^{\text {th }}$ from $80^{\text {th }}$. The purpose of this study is to look into the regulatory framework in India for insolvency and bankruptcy. The impact of insolvency and bankruptcy Code on the Indian economy is also discussed in the study.

KEYWORDS: Insolvency, Bankruptcy, Code, Regulatory, SARFAESI Act, National Company Law Appellate Tribunal (NCLAT)
\end{abstract}

\section{INTRODUCTION}

Historically, bankruptcies have been strongly linked to the economic cycle. Failure of certain company strategies is a natural part of the market economy's process. When a firm fails, the optimum outcome for society is a quick renegotiation between financiers, to fund the going concern with a new structure of obligations and a new management team. The purpose of bankruptcy legislation is to recover an entity's debt and distribute its assets among competing claimholders. As a result, the RBI's asset quality reviewers identified an extremely high number of NPAs. The government's most major change is the insolvency and bankruptcy legislation.

Bankruptcy is a legal state, whereas insolvency is a circumstance. Insolvency simply means that you are unable to pay your debts. The end result is insolvency. Although a bankrupt might become insolvent, not all insolvencies result in a bankruptcy filing. Insolvency is a financial situation in which a business or individual is unable to pay their bills on time, whereas bankruptcy is the legal procedure through which a person is declared insolvent. After less formal attempts to improve one's financial status have failed, an insolvency process may be initiated. As a result, a person's insolvency might be exacerbated by a lack of finances and liquidity, making debt repayment nearly difficult.

On the heels of the adoption of the Insolvency and Bankruptcy Code, India jumped from $108^{\text {th }}$ to $52^{\text {nd }}$ in the resolving insolvency category, while its rating im proved significantly in dealing with construction permit $\mathrm{s}$ to $27^{\text {th }}$ from $52^{\text {nd }}$ and trading across borders to $68^{\text {th }}$ from $80^{\text {th }}$. According to the rankings, India has risen 14 places to $63^{\text {rd }}$ place out of 190 countries. New Zealand remained in first place and Somalia remained in $190^{\text {th }}$ place, respectively. In the 12 month period ending $1^{\text {st }}$ May, 2019, the indicator analyses the performance of nations across ten key parameters. The World Bank is expanding its ease of doing business study to two 
additional cities starting in 2020, Bengaluru and Kolkata in addition to Delhi and Mumbai. According to The Doing Business 2020 assessment, India's score rose from 67.3 in 2018 to 71.0 in 2019 , making it one of the top 10 most improved nations for the third time. Despite a dip in score, India's standing in registering property rose from $166^{\text {th }}$ to $154^{\text {th }}$.

Figure-1: Meaning of Insolvency

\section{Insolvency}

- Stock-base insolvency: the value of the firm's assets is less than the value of the debt.

Solvent firm

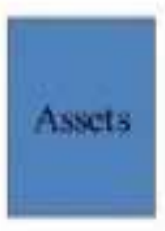

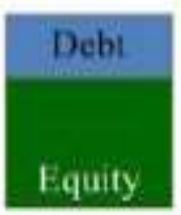

Insolvent firm
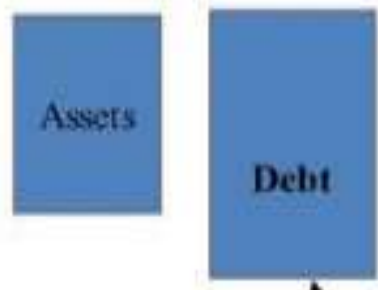

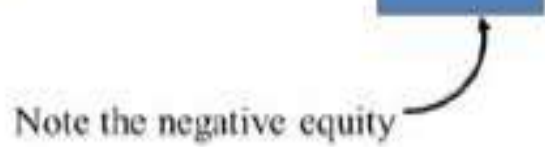

\section{Source: https://taxguru.in/corporate-law/difference-insolvency-bankruptcy.html}

It signifies that the overall money inflows and assets combined are fewer than the liabilities of a corporation. It manifests itself in cash flow problems, the loss of commercial contracts, a drop in sales, the loss of clients, and poor credit ratings, among other things. As a result, a lack of finances and liquidity can make debt repayment very impossible, rendering a person bankrupt. Bankruptcy is a legal process that is initiated when a person is unable to satisfy his or her financial responsibilities or has no reasonable expectation of being able to repay his or her debts when they become due in the future.
1. It begins with the debtor or creditor filing an application with an authorised authority or court declaring themselves insolvent.

2. As a result, the court must decide whether the petition should be accepted or dismissed.

3. After the petition is accepted, the court determines how the insolvent's personal assets will be distributed among creditors or banks.

As a result, when a person files a bankruptcy petition, he is obligated to pay back what he owes, for which he seeks assistance from the court. 
Figure -2: Concept of Insolvency, Bankruptcy and Liquidation

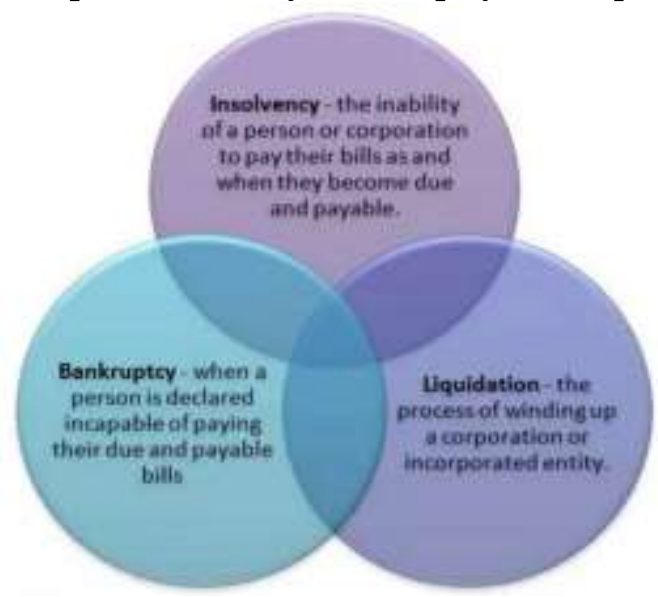

Source: https://www.civilsdaily.com/burning-issue-insolvency-and-bankruptcy-code/

In an essence, both bankruptcy and liquidation are examples of insolvency. Failure to pay debts when they are due and payable is the most common reason for Liquidation, and it is the only way a natural person may go bankrupt. The winding up of a company or incorporated organisation is referred to as liquidation.

\section{OBJECTIVES OF THE STUDY}

The study focuses on understanding the following objectives in light of consolidated law for insolvency and bankruptcy for corporations, partnerships, and individuals:

1. To comprehend conceptual framework of the Insolvency and Bankruptcy.

2. To find out the trend of Insolvency and Bankruptcy practices.

3. To elaborate the legal framework in India

4. To examine the pattern of cases that have been admitted and settled under the IBC

\section{METHODOLOGY}

A secondary source was used to gather the information. The information was gathered from the quarterly bulletins of the Insolvency and Bankruptcy Board of India (IBBI), Reserve Bank of India (RBI), Ministry of Corporate Affairs (MCA), National Company Law Tribunal (NCLT), and others. To analyse the trend of CIRP initiations, sectoral distribution of CIRPs, voluntary liquidation, and other topics, simple statistical methods such as ratios and correlation are utilised.

\section{THE EVOLUTION OF BANKRUPTCY LAWS IN INDIA}

On the Government of India's request, the Law Commission has taken up the modification of the Insolvency Law. Insolvency law in India, like most other laws, has its roots in English law. The Bankruptcy Law was solely a product of legislation. The Bankruptcy Acts approved by the British Parliament in 1889, 1869, 1883, and 1914 are the most important statutes on the issue. The next step was reached in 1828 with the passage of Statue 9. The first insolvency court was founded in 1828 by an act enacted in the Presidency-towns. These courts were established primarily to help bankrupt debtors.

Bankruptcy is constituted a crime, and a bankrupt under the ancient legislation is designated an offender. The 1848 Indian Insolvency Act was enacted to address the problem of insolvency in India. The previous permissions were cancelled in 1848, and a new Act, known as the Indian Insolvency Act, was enacted. All merchants and non-brokers make special reference to the requirements of the Act. This Act intended to shift the Courts created by the Act of 1828 only for the relief of insolvent debtors, but the Courts were to be held under the constant supervision of Supreme Court judges. The Act of 1848 remained in effect in the Presidency-towns until the current Presidency-towns Insolvency Act, 1909, was enacted in 1909.

The Provincial Insolvency Act of 1920 abolished the 1909 Act. This Act, which covers individual insolvency and several sections that also govern corporate insolvency, is currently in effect in India. Cities where the government is located the 1909 Insolvency Act was enacted to help those who were 
facing financial difficulties. The Indian Insolvency Act, 1848, was thought to be archaic in ahead of the agenda in the twentieth century.

The Indian Constitution, enacted in 1950, includes terminology like "insolvency" and "bankruptcy" in the third list of Schedule 7, referred to as the concurrent List. The Union List, on the other hand, includes terminology such as company incorporation, command, and liquidation. With these characteristics, or strong points, established in the Constitution, the Companies Act of 1956 was enacted, giving the corporate sector a new structure. In reality, this Act comprised almost all laws pertaining to or relating to the operations of corporations, as well as the procedure of dissolution.

It's even thought to have reduced fraudulent activity. However, despite the fact that the Act was a good initiative by the government, the other fact that attempts to say that this Act never made any sense with regard to expressions like insolvency or bankruptcy and has no power to deal with debt payment despite the fact that this Act was the primary law for the purpose of adjusting corporate bankruptcy. Actions taken by different Acts are given in Table-1.

Table- 1: The Recovery Action by Creditors in Different Acts

\begin{tabular}{|l|l|l|l|}
\hline Sl. No. & \multicolumn{1}{|c|}{ Action } & \multicolumn{1}{|c|}{ Details of Act } & 1872 \\
\hline 1. & Recovery Action & Indian Contract Act & 1993 \\
\cline { 3 - 4 } & & Recovery of Debts Due to Banks and Financial Institutions Act \\
\hline 3. & Has not had Desired Outcomes & $\begin{array}{l}\text { Securitisation an Reconstruction of Financial Assets and } \\
\text { Enforcement of Security Interest Act }\end{array}$ & 2002 \\
\hline 4. & $\begin{array}{l}\text { Have Neither been Able to Aid } \\
\text { Recovery for Lenders nor Aid } \\
\text { Restructuring of Firms }\end{array}$ & The Sick Industrial Companies (Special Provisions) Act & 1985 \\
\hline 5. & $\begin{array}{l}\text { The Winding-up provisions of the Companies Act } \\
\text { Insolvealing with Individual }\end{array}$ & The Presidential Towns Insolvency Act & 1956 \\
\cline { 4 - 5 } & & The Provincial Insolvency Act & 1909 \\
\hline 7. & & &
\end{tabular}

\section{Sources: http://www.arthapedia.in}

In Table- 1 it can be observed that some Acts are taken recovery actions. However, there was a period when the Act known as "The Companies (Amendment) Act, 2003" suggested a slew of modifications to the insolvency-related provisions of the Companies Act, 1956. However, due to actual obstacles, these could not be effective. Following that, the new Companies Act was passed in 2013 and a substantial amount of the 2013 Act's provisions were in line with those outlined in the last modification, which took place in 2002. The implementation of corporate insolvency remedies has advanced in lockstep with the new Companies Act of 2013.

Bankruptcies are a taboo issue in India, despite the fact that they are a common occurrence in the worldwide corporate sector. Promoters would rather create a false sense of success than reveal that a firm is going bankrupt. Because of this, the government was obliged to pass the Insolvency and Bankruptcy Code.

The Insolvency laws in India have their origin in English Law. The provisions that dealt with insolvency law were initially found under ss.23 and 24 of the Government of India Act 1800. In 1828, a Statute was passed marking the beginning of insolvency specific legislation in India. This statute applied to Presidency towns namely Bombay, Madras and Calcutta. Then the Indian Insolvency Act 1848 was enacted that made distinction between traders and nontraders. The jurisdiction relating to insolvency was transferred to High Courts, limiting its jurisdiction to presidency towns. In 1909, the Presidency Towns Insolvency Act 1909 was passed. Till 1907, there was no legislation dealing with insolvency in nonpresidency areas, therefore, in 1907, the Provincial Insolvency Act was passed which was later replaced by the Provincial Insolvency Act 1920.

These two legislations continued in force until recently and were repealed by the IB Code insolvency laws in India have their origin in English Law. The provisions that dealt with insolvency law were initially found under ss.23 and 24of the Government of India Act 1800. In 1828, a Statute was passed marking the beginning of insolvency specific legislation in India. This statute applied to Presidency towns namely Bombay, Madras and Calcutta. Then the Indian Insolvency Act 1848 was enacted that made distinction between traders and non-traders. The jurisdiction relating to insolvency was transferred to High Courts, limiting its jurisdiction to presidency towns. In 1909, the Presidency Towns Insolvency Act 1909 was passed. Till 1907, there was no legislation dealing with insolvency in non-presidency areas, therefore, in 1907, 
the Provincial Insolvency Act was passed which was later replaced by the Provincial Insolvency Act 1920. These two legislations continued in force until recently and were repealed by the IB Code The Insolvency laws in India have their origin in English Law. The provisions that dealt with insolvency law were initially found under ss.23 and 24 of the Government of India Act 1800. In 1828, a Statute was passed marking the beginning of insolvency specific legislation in India. This statute applied to Presidency towns namely Bombay, Madras and Calcutta. Then the Indian Insolvency Act 1848 was enacted that made distinction between traders and non-traders. The jurisdiction relating to insolvency was transferred to High Courts, limiting its jurisdiction to presidency towns. In 1909, the Presidency Towns Insolvency Act 1909 was passed. Till 1907, there was no legislation dealing with insolvency in non- presidency areas, therefore, in 1907, the Provincial Insolvency Act was passed which was later replaced by the Provincial Insolvency Act 1920. These two legislations continued in force until recently and were repealed by the IB Code

Prior to the Code, India lacked a comprehensive law controlling episodes of corporate insolvency and bankruptcy. Provisions relating to corporate insolvency, for example, were scattered across laws as diverse as the Recovery of Debts Due to Banks and Financial Institutions Act, 1993 (RDDB Act), the Companies Act, 1956 (Companies Act), the much-maligned Sick Industrial Companies (Special Provisions) Act, 1985 (Sick Industrial Companies (Special Provisions) Act (SICA), and the Securitization and Reconstruction of Financial Assets and Enforcement of Security Interest Act, 2002. (SARFAESI Act).

This Act only applies to non-performing asset (NPA) loans with an outstanding balance of more than Rs. 1 lakh. Furthermore, under this Act, NPA loan accounts with a balance of less than $20 \%$ of the principal and interest are not eligible for resolution. While the SARFAESI Act covers how financial institutions can deal with assets, the IBC addresses the interests of all creditors, including operational and financial creditors, as well as secured and unsecured creditors.

17 large stores declared bankruptcy last year. Payless, Gymboree, and Charming Charlie were among those who returned to court for the second time. As liquidations grew in 2019, bankruptcy proved deadly for many retailers. Last year, companies shuttered more than 9,500 outlets. In table- 2 some biggest bankruptcies in India have been depicted.

Table-2: Biggest Bankruptcies in India in Last Years

\begin{tabular}{|l|l|l|l|}
\hline Sl. No. & \multicolumn{1}{|c|}{ Company Name } & \multicolumn{1}{c|}{ Amount } & Year \\
\hline & Dewan Housing Finance Ltd. & US\$ 13.93 billion & 2019 \\
\hline & Bhushan Power and Steel & US\$ 6.9 billion & 2019 \\
\hline & Essar Steel & US\$ 6.9 billion & 2017 \\
\hline & Lanco Infra & US\$ 6.3 billion & 2017 \\
\hline & Bhushan Steel & US\$ 6.2 billion & 2019 \\
\hline & Reliance Communications & US\$ 4.6 billion & 2017 \\
\hline & Alok Industries & US\$ 4.1 billion & 2017 \\
\hline & Jet Airways & US\$ 2 billion & 2019 \\
\hline
\end{tabular}

Sources: tradebrains.in/biggest-bankruptcies-in-india/

From the table it can be seen that in last some years Bankruptcies in India.

\section{SARFAESI Act 2002}

The Securitisation and Reconstruction of Financial Assets and Enforcement of Security Interests Act, 2002 (SARFAESI Act) authorised banks or financial institutions with a presence in India or that have been notified by the Government of India to recover on non-performing assets without the intervention of the courts. Non-performing assets are those that have not been paid interest or principal payments for longer than 180 days.

The SARFAESI Act provides three alternative ways for recovering non-performing assets, which would include taking possession, selling, and leasing the assets underlying the security interests, such as movable property (tangible or intangible, including accounts receivable) and immovable property, without involving the courts. It's difficult to imagine that such massive bankruptcies have occurred at first. However, in retrospect, they provide excellent business insights. The word 'debt' has been a recurring motif in all of them. If used appropriately, it may help the company flourish or it might lead to the same destiny as the firms mentioned above. 


\section{Reason behind the Insolvency and Bankruptcy Code, 2016}

Sick Industrial Companies (Special Provisions) Act, 1985 (SICA), Recovery of Debt Due to Banks and Financial Institutions Act, 1993 (RDBFIA), Securitization and Reconstruction of Financial Assets and Enforcement of Security Interest Act, 2002 (SARFAESI), and the Companies Act, 2013 all dealt with insolvency and bankruptcy of Indian companies, limited liability partnerships, partnerships firms, individuals, and other legal entities. As a result, High Courts, District Courts, the Company Law Board, the Board for Industrial and Financial Reconstruction (BIFR), and Debt Recovery Tribunals (DRTs) all have jurisdiction at different stages of the process, potentially leading to systemic delays and complexities. While high courts handle company liquidations, individual cases are handled under the Presidency Towns Insolvency Act, 1909 and Provincial Insolvency Act, 1920. The current regulatory structure hinders lenders' ability to recover defaulted assets effectively and quickly, putting unnecessary burden on the Indian credit system.

\section{Insolvency and Bankruptcy Code (IBC), 2016}

1. The major goal of the IBC is to consolidate and update insolvency laws for corporations, partnership entities, and individuals in a timely way.

2. The second order aim is to maximise the value of the firm's assets, and

3. The third order objective is to promote entrepreneurship, make credit available, and balance the interests of all stakeholders.

\section{A. Basic Structure of the IBC}

There are 5 parts and 255 sections in this code.

Part I is "preliminary," focusing on "insolvency resolution and liquidation for corporations," Part II on "insolvency resolution and bankruptcy for individuals and partnership firms," Part III on "insolvency resolution and bankruptcy for individuals and partnership firms," Part IV on "regulatory aspects of insolvency professionals, agencies, and information utilities," and Part V on "other matters."

B. Institutional Framework under the IBC

The essential pillar for efficient execution of any statute is the institutional structure. The IBC is built on four pillars that efficiently assist the insolvency and bankruptcy procedure.

Figur-3: Insolvency Procedure

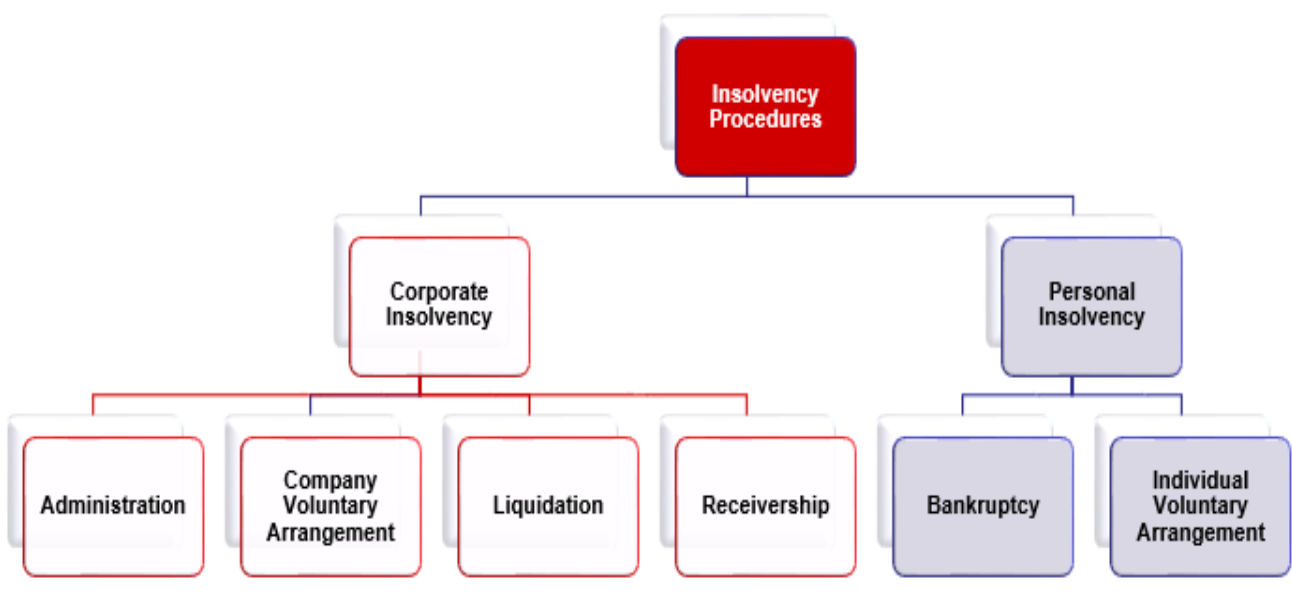

Source: www.quora.com

\section{Corporate Insolvency Resolution Process (CIRP)}

According to Part II of Chapter II of the IBC, the Corporate Insolvency Resolution Process can be started by Financial Creditors (FC), Operational Creditors (OC) (including Government/ Employees or Workmen), or the Corporate Debtor (CD) itself by filing an application with the adjudicating authority, the National Company Law Tribunal, when a corporate debtor makes a default, whether in part or whole, or an instalment of the amount owed or interest thereon of a minimum of Rs. 1 lakh.

The law of insolvency is a social law that was created to offer relief to honest debtors who have become unable to repay their obligations owing to unanticipated or tragic circumstances. Its goal is also to provide an equitable division of a debtor's estate among his creditors, as well as to free him from accountability for his debts and obligations under specific situations. 
Types of Bankruptcy

Despite the fact that the fundamental purpose of bankruptcy is to eliminate debt, not all bankruptcies are the same. There are really six main sorts of bankruptcies:

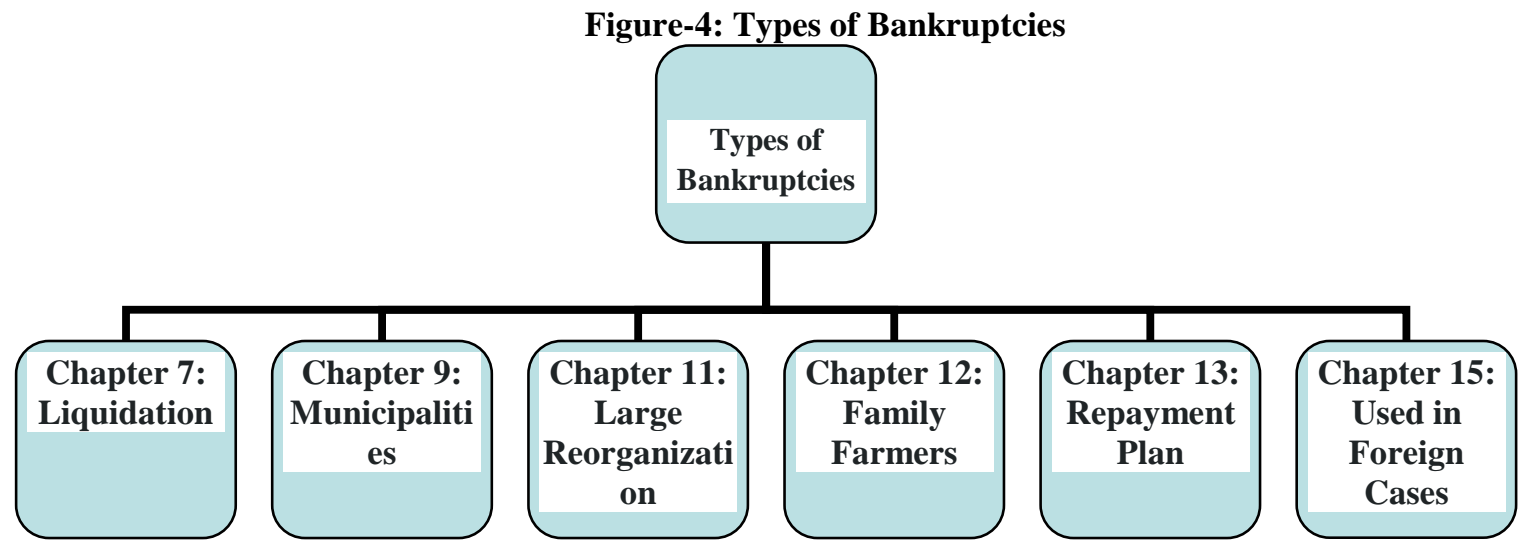

Source: https://www.managementnote.com/types-of-bankruptcy-law/

\section{Chapter 7 Bankruptcy}

Chapter 7 bankruptcy, often known as liquidation or straight bankruptcy, is the most prevalent kind of personal bankruptcy. The liquidation (selling) of your assets (everything you possess that has worth) to pay off your creditors is overseen by a courtappointed trustee (the people you owe money to). Any unsecured debt (such as credit card debt or medical expenses) is usually forgiven. However, as previously stated, this does not cover debts that are not forgiven by bankruptcy, such as education loans and taxes.

\section{Chapter 9 Bankruptcy}

Another repayment strategy is Chapter 9 bankruptcy, which allows municipalities, cities, school districts, and other entities to reorganise and repay their debts.

\section{Chapter 13 Bankruptcy}

While Chapter 7 bankruptcy often results in debt forgiveness, Chapter 13 bankruptcy essentially reorganises your debt. A monthly payment plan is approved by the court, allowing you to pay back a part of your unsecured debt and all of your secured debt over the course of three to five years. The amount of your monthly payment is determined by your income and the amount of debt you owe. However, the court has the authority to place you on a strict budget and monitor all of your expenditures.

Unlike Chapter 7, this type of bankruptcy allows you to maintain your assets while catching up on non-bankruptcy debts. Chapter 13 can also help you avoid foreclosure by allowing you to catch up on your mortgage payments.

\section{Chapter 11 Bankruptcy}

Chapter 11 bankruptcy is most commonly used to restructure a business or corporation. Businesses must devise a strategy for how they will continue to operate while paying off their debt, which must be approved by both the court and the creditors. Some people, like as real estate investors, may opt to file under Chapter 11 if they have too much debt to qualify for Chapter 13 but have a lot of high-value properties and assets. You're probably not going to tamper with this one unless you're a pro athlete or a celebrity.

\section{Chapter 12 Bankruptcy}

This is a repayment arrangement that helps family farmers and fishermen to avoid having to sell all they own or having their property foreclosed on. While Chapter 12 bankruptcy is comparable to Chapter 13, it is more flexible and has larger debt limits.

\section{Chapter 15 Bankruptcy}

Chapter 15 of the United States Bankruptcy Code deals with international bankruptcy concerns and enables foreign debtors access to US bankruptcy courts.

\section{Insolvency and Bankruptcy Board of India}

Under the Insolvency and Bankruptcy Code, 2016, the Insolvency and Bankruptcy Board of India was constituted on October 1, 2016. (Code). It is a critical pillar of the ecosystem, responsible for enacting the Code, which consolidates and amends the laws governing the reorganisation and insolvency resolution 
of corporate persons, partnership firms, and individuals in a timely manner in order to maximise the value of such persons' assets, promote entrepreneurship, increase credit availability, and balance the interests of all stakeholders.

\section{Objectives of Insolvency and Bankruptcy Board of India}

1. Regulator It's a one of a

kind regulator that oversees both professions and procedures.

It regulates insolvency professionals, insolvency $\mathrm{p}$ rofessional agencies, insolvency professional entit ies, and information utilities.

2. Under the Code, write and implement regulations for procedures such as corporate insolvency resolu tion, corporate liquidation, individual insolvency $r$ esolution, and individual bankruptcy.

3. In order to achieve the Code's goals, promote the growth of insolvency professionals, insolvency pr ofessional agencies, information utilities, and othe $\mathrm{r}$ organisations, and regulate their work and practi ses.

4. It has also been appointed as the 'Authority' under the Companies (Registered Valuers and Valuation Rules), 2017 for the regulation and growth of the country's valuer profession.

\section{Current Position of Bankruptcy Law in Different Countries}

The United Kingdom, Singapore, and India are nominally common law countries. However, bankruptcy law has developed differently in each of the three countries, with quite diverse effects. The United Kingdom is ranked $13^{\text {th }}$ in the World Bank's 2015 'Doing Business' Report's Resolving Insolvency indicator, whereas Singapore is ranked 27th and India is ranked $136^{\text {th }}$.

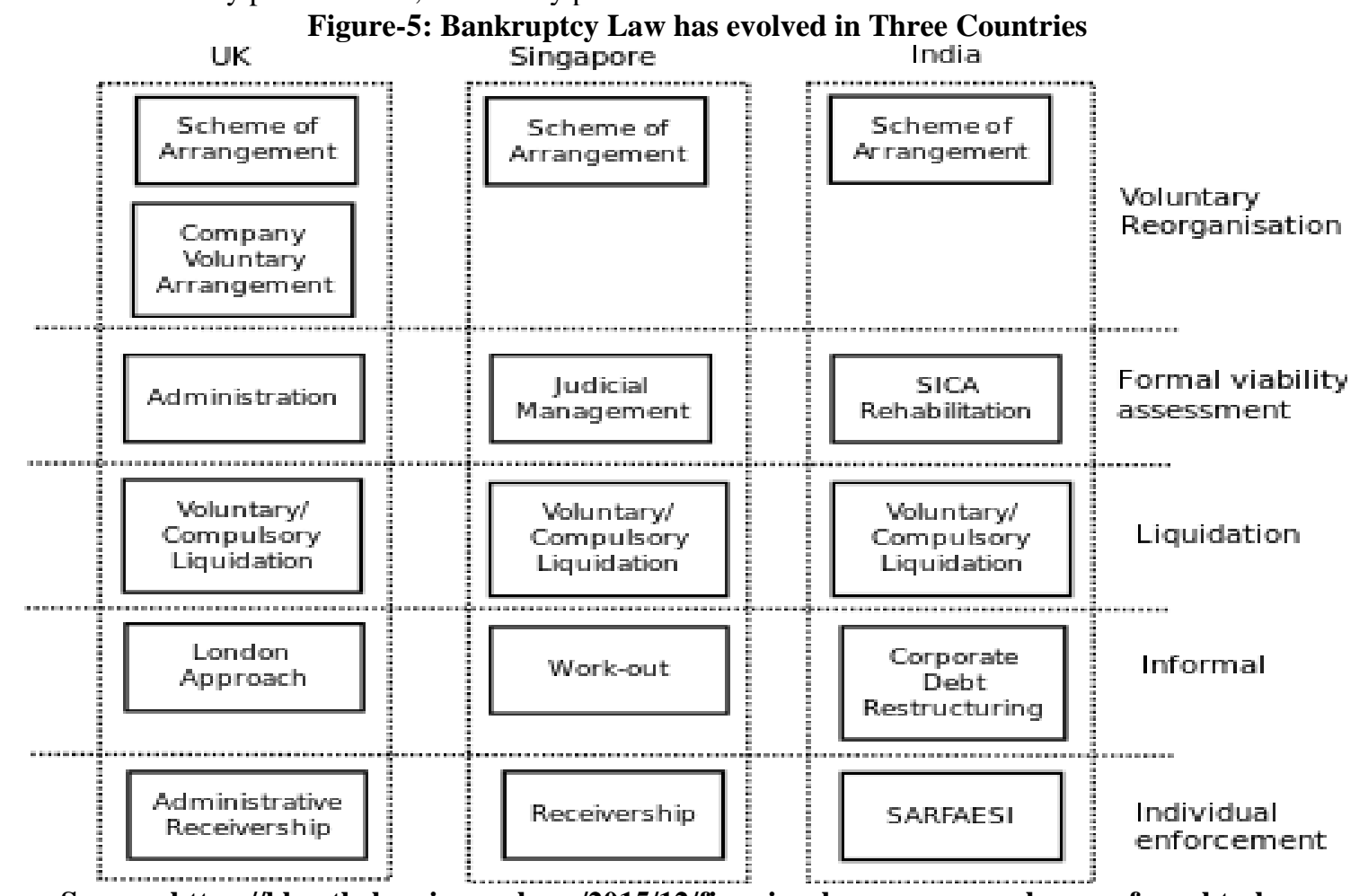

Source: https://blog.theleapjournal.org/2015/12/firm-insolvency-process-lessons-from.html

The processes for corporate insolvency in the three countries are depicted in Figure 1. The formal processes are included in a single statute in the United Kingdom and Singapore (save for the Scheme of Arrangement in the United Kingdom, which is contained in the Companies Act), however they are dispersed among multiple laws in India.
Corporate bankruptcy was covered by the Companies Act in the United Kingdom until 1985. The Insolvency Act, a comprehensive statute dealing with insolvency of corporations and people, was adopted in the United Kingdom in 1986. The Companies Act, which governs corporate insolvency in Singapore, offers processes for reorganisation and liquidation. In 
India, the Companies Acts of 1956 and 2013 have (inadequate) procedures for liquidation. Through the Sick Industrial Enterprises Act, reorganisation is only allowed to specific categories of industrial companies (SICA 1985).

Figure-6: Resolving Insolvency and Global Recovery Rate of various Counties
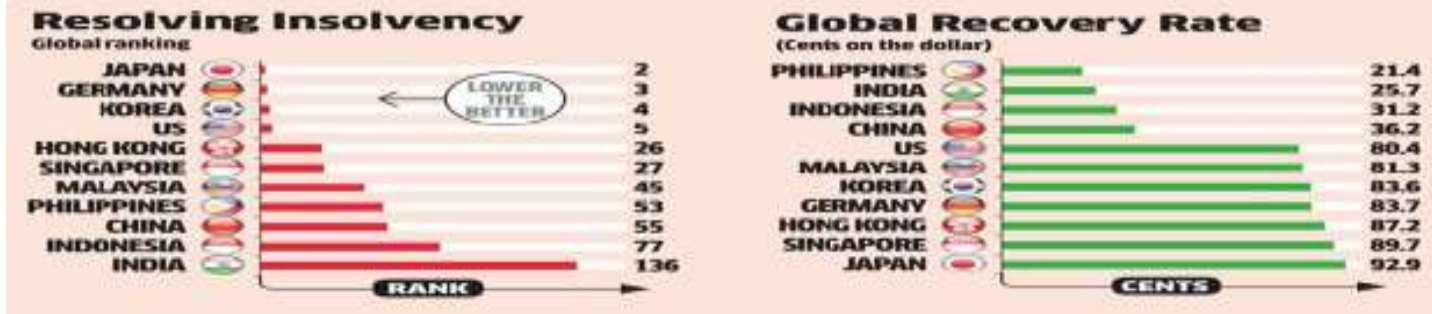

Source: Aditya Vasa, Bankruptcy Code, 2016 - Key Developments, January 11, 2018

The graphic above depicts the rank and recovery rate of several counties. Japan is ranked second, while India is ranked 136 for resolving insolvency. In terms of global recovery rate, Japan has a rate of 92.9 percent, while India has a rate of 25.7 percent.

\section{Current Position of Bankruptcy in India}

Table-3: Details of CIRPs, CIRP closed and Liquidations between April 1st, 2020 and December 31 st, 2020

\begin{tabular}{|l|l|l|}
\hline Sl. No. & Details & No. \\
\hline 1. & Corporate Insolvency RESOLUTION processes (CIRP) & 76 \\
\hline 2. & CIRPs were Closed due to Withdrawal or Appeal or Settlement & 128 \\
\hline 3. & Companies went into Liquidation. & 189 \\
\hline
\end{tabular}

Source: https://pib.gov.in/PressReleasePage.aspx?PRID=1706640

Defaults occurring between March 25, 2020, and the conclusion of the suspension period will be treated as "non existent" for the purposes of instituting
After the declaration of the statewide lockdown last year, 1,419 CIRPs generated orders for liquidation, with a liquidation value of Rs 52,036 crore," Finance and Corporate National Company Law Tribunals (NCLT) throughout the country admitted a total of 283 enterprises into bankruptcy amid the epidemic.

Table-4: No. of Firms Filed for Bankruptcy as per the NCLT

\begin{tabular}{|c|c|c|}
\hline Sl. No. & Year & No. of Companies filed for Bankruptcy \\
\hline 1. & 2018 & 149 \\
\hline 2. & 2019 & 103 \\
\hline 3. & 2020 & 72 \\
\hline & Total & $\mathbf{3 2 4}$ \\
\hline
\end{tabular}

Source: https://www.livemint.com/news/india/over-300-companies-filed-for-bankruptcy-in-past-3-years-saysgovt-11615898321296.html

According to the NCLT, the following claims were submitted under the Insolvency and Bankruptcy Code in various years: 
Table-5: As per NCLT Applications were filed under the Insolvency and Bankruptcy Code

\begin{tabular}{|l|l|l|}
\hline Sl. No. & Year & NCLT Applications \\
\hline 1. & 2018 & 8,330 \\
\hline 2. & 2019 & 12,091 \\
\hline 3. & 2020 & 5,282 \\
\hline
\end{tabular}

Source:https://www.indiainfoline.com/article/news-top-story/mca-324-companies-filed-for-bankruptcy-inthree-years-up-to-2020-121031700149_1.html

As a result, the number of applications submitted in the last three years does not appear to have increased.

According to the Corporations Act of 2013, companies must convene an Annual General Meeting (AGM) within six months after the end of the fiscal year. As a result, within 30 days of the AGM, financial statements and a board report incorporating CSR disclosure must be filed in the MCA21database. As a result, no CSR-mandated enterprises have filed for the current fiscal year.

Lenders, emboldened by the country's new bankruptcy law and keen to clear up soured debt off their books, began seizing assets of delinquent enterprises or dragging them into insolvency, making 2019 a bad year for many Indian tycoons. In the 18 months leading up to September, Indian banks wrote down a record $\$ 39$ billion in loans in an effort to rebuild their balance sheets as they faced the world's greatest bad debt pile. A shadow banking crisis exacerbated the situation, causing a funding crunch.

Prior to the introduction of the Insolvency and Bankruptcy Code, 2016 (IBC, 2016 or code), India's legal framework for dealing with insolvency and restructuring procedures affecting corporate entities, partnership firms, and individuals was exceedingly complicated and fragmented, encompassing various legislation such as the Companies Act of 1956, the Sick Industrial Companies (Special Provisions) Act of 1985, and the Securitisation and Reconstruction of Financial Assets Act of 1992 and Enforcement of Securitization Agreements Act, and the Securi Multiple laws, forums, and complications caused delays in the prompt resolution of troubled organisations, partnership businesses, or people, resulting in a devaluation of the borrower's assets and rendering bankruptcy negotiations obsolete.

It was founded on October 1, 2016, and the Insolvency and Bankruptcy Code, which was approved by the Lok Sabha on May 5, 2016, gave it legislative powers. Individuals, companies, limited liability partnerships, and partnership businesses are all covered. The new regulation will shorten the time it takes to resolve strained assets in the country. It aims to make the insolvency and bankruptcy procedure as simple as possible. NCLT (National Company Law Tribunal) and Debt Recovery Tribunal are the two tribunals that deal with the matters.

\section{CONCLUSION}

The crucial focus of current bankruptcy legislation and finance obligation reconstruction acts is not on the liquidation and discontinuance of insolvency matters, but rather on the renewal of capital and gradable construction of account holders confronting money issues in order to allow them to restore and operate their businesses.

An examination of the three nations' laws and procedures reveals crucial lessons for India's corporate bankruptcy reform. The purpose of insolvency law is twofold: to protect debtors from the harassing of creditors whose claims he is unable to meet, and to establish a mechanism by which creditors who are not secured in the payment of their debts might be satisfied.

The IBC Code has aided India's global ranking in terms of ease of doing business. For the first time, India is among the top 100 countries in the globe. This increase is due to economic reforms such as the IBC.

\section{REFERENCES}

1. Adler, B.E. (2002), The Law of last resort. Vanderbilt Law Review, 55(6), 1661-1698.

2. Aumann, R. (2010), Some non-superadditive games, and their Shapley values, in the Talmud. International Journal of Game Theory 39, 3-10.

3. Baird, D.G., Bernstein, D.S. (2006), Absolute priority, valuation uncertainty, and the reorganization bargain. Yale Law Journal, 115, 949-950.

4. Baird, D.G., Rasmussen, D.K. (2003), Chapter 11 at twilight. Stanford Law Review, 56, 673-674.

5. Bankruptcy Abuse Prevention and Consumer Protection Act. (2005), Available from: https://www.govtrack.us/congress/bills/109/s256.

6. Fowler v Padget (1798) 7 Term Rep 509; 101 ER 1103 is an old UK insolvency law case, which concerned what amounted to an act of bankruptcy.

7. Holsworth, H.E.L. (1938), Vol. XI Pages 445-446 \& Vol. VIII Pages 229-245

8. https://indianexpress.com/article/explained/explain ed-what-helped-india-go-to-63rd-spot-in-ease-ofdoing-business-6085344/ 
9. https://www.iasgyan.in/daily-current-affairs/dailynews-analysis-25-october-2019-10-25

10. https://www.ibbi.gov.in/about

11. https://www.livemint.com/news/india/india-jumps14-notches-in-world-bank-s-ease-of-doingbusiness-rankings-11571882591868.html

12. https://www.mca.gov.in/content/mca/global/en/abo ut-us/affiliated-offices/ibbi.html

13. https://www.studyadda.com/current-affairs/ranksreports/india-ranked-63rd-in-world-bank-s-ease-ofdoing-business-ranking/18065

14. Ministry of Law under orders in file No. 22-V-L of the Legislative Section

15. Mulla Law of Insolvency in India (1958), P.16 